JURNAL SOSAINS

JURNAL SOSIAL DAN SAINS

VOL 2 NO 22022

P-ISSN 2774-7018, E-ISSN 2774-700X

\title{
MENINGKATKAN PERAN USAHA KECIL DAN MIKRO SYARIAH DALAM MENGATASI KEMISKINAN
}

\author{
Muhammad Risal dan Siradjuddin \\ Fakultas Ekonomi dan Bisnis Islam, Universitas Islam Negeri \\ Alauddin Makassar, Indonesia \\ Email : Ichal.k11.mr@gmail.com dansiradjuddin@uin- \\ alauddin.ac.id
}

Info Artikel :

Diterima : 17 Januari 2022

Disetujui : 08 Februari 2022

Dipublikasikan : 15 Februari 2022

\begin{abstract}
ABSTRAK
Kata Kunci:

Latar Belakang : Usaha kecil dan mikro syariah sebagian besar tumbuh secara Keterampilan Usaha kecil dan mikro, Syariah tradisional dan merupakan usaha keluarga yang turun temurun. Keterbatasan kualitas SDM usaha keci ldan mikro syariah berpengaruh terhadap manajemen pengelolaan usahanya, sehingga usaha tersebut sulit untuk berkembang dengan optimal. Tujuan : Tujuan Penelitian ini untuk meningkatkan produktivitas UMKM, mendorong kreavitas program dan kegiatan yang berkaitan dengan pemberdayaan UMKM. Metode : Jenis penelitian yang digunakan penelitian kualitatif dengan metode literatur review yaitu penelitian yang menggunakan beberapa kajian untuk kemudian dapat dipahami dan dijadikan dalam satu bentuk pemaparan. Kami mengumpulkan teori-teori dari beberapa sumber yang berasal dari artikel maupun buku-buku yang relevan. Hasil : Dalam pengembangan usaha kecil dan mikro syariah, bukan semata-mata langkah yang harus diambil oleh Pemerintah dan hanya menjadi tanggung jawab Pemerintah. Pihak usaha kecil dan mikro syariah sendiri sebagai pihak internal yang dikembangkan, dapat mengayunkan langkah bersama-sama dengan Pemerintah. Karena potensi yang mereka miliki mampu menciptakan kreativitas usaha dengan memanfaatkan fasilitas yang diberikan oleh pemerintah. Kesimpulan : Perkembangan usaha mikro kecil di Indonesia yang semakin meningkat setiap tahunnya memberikan angin segar bagi bangkitnya sektor perekonomian, selain peran UMKM yang dapat mengurangi kemiskinan dan pengangguran juga dapat meratakan perekonomian serta memberikan devisa bagi negara.
\end{abstract}

\section{ABSTRACT}

Background : Sharia small and micro businesses mostly grow traditionally and are

Keywords: Skills, Small and Micro Enterprises, Sharia family businesses that have been passed down from generation to generation. The limited quality of human resources for sharia micro and small businesses affects the management of their business, so that the business is difficult to develop optimally. Purpose : The purpose of this study is to increase the productivity of MSMEs, encourage the effectiveness of programs and activities related to MSME empowerment. Method: The type of research used is qualitative research with the literature review method, namely research that uses several studies to then be understood and made into one form of exposure. We collect theories from several sources from relevant articles and books. Results : In the development of sharia small and micro businesses, it is not merely a step 
that must be taken by the Government and is only the responsibility of the Government. The sharia small and micro businesses themselves as internal parties that are developed, can take steps together with the Government. Because the potential they have is able to create business creativity by utilizing the facilities provided by the government. Conclusion : The development of micro and small enterprises in Indonesia which is increasing every year provides fresh air for the rise of the economic sector, in addition to the role of MSMEs that can reduce poverty and unemployment, they can also level the economy and provide foreign exchange for the country.

\section{PENDAHULUAN}

Tidak hanya sekedar masalah Kesehatan, pandemi Covid-19 juga berdampak meningkatnya angka kemiskinan sepanjang tahun 2019 hingga 2021 (Darmawan \& Desiana, 2021). Peningkatan jumlah penduduk miskin itu terjadi lantaran pandemi menyebabkan banyak kegiatan perekonomian tidak bisa berjalan seperti biasa sehingga pendapatan masyarakatpun tertekan, bahkan sebagian masyarakat lainnya kehilangan mata pencahariannya (Fadhli, Himmah, \& Taqiyuddin, 2021). Data dari BPS tahun 2019 menyebutkan terdapat 24,7 juta penduduk miskin di Indonesia dan ditahun 2020 mencapai 26,42 juta penduduk. Jika persoalan virus corona ini tidak mampu diselesaikan maka pada tahun ini angka kemiskinan tersebut tidak mustahil akan mengalami peningkatan. Hal ini disebabkan oleh kekuatan ekonomi yang semakin melemah mengakibatkan peningkatan kemiskinan (Nurhidayat, 2020) .

Ada beragam definisi berkaitan dengan kemiskinan dan pengukurannya. Badan Pusat Statistik (BPS) mengukur kemiskinan dengan menggunakan konsep kemampuan memenuhi kebutuhan dasar (basic needs approach). Untuk mengukur kemiskinan diperlukan standar yang disebut garis kemiskinan, garis kemiskinan ini mencerminkan nilai rupiah pengeluaran minimum yang diperlukan seseorang untuk memenuhi kebutuhan pokok hidupnya selama sebulan (Maipita, 2013). Dalam Islam salah satu pengertian kemiskinan adalah keadaan dimana manusia tidak dapat mencukupi kebutuhan hidupnya untuk beribadah kepada Allah swt, kebutuhan hidup yang dimaksud disini adalah agama, kesehatan jasmani, intelektualitas atau pengetahuan, keturunan dan harta (Abdillah Ahsan, Wiyono, Ir, \& Demografi, 2018).

Penyebab munculnya kemiskinan bisa dilihat dari sudut pandang Mikro (Indika \& Marliza, 2019). Secara Mikro ada tiga penyebab munculnya kemiskinan, antara lain kemiskinan muncul karena adanya ketidaksamaan pola kepemilikan sumberdaya yang menimbulkan distribusi pendapatan yang timpang (Kadji, 2012). Penduduk miskin hanya memiliki sumberdaya dalam jumlah terbatas dan kualitasnya rendah, kemiskinan muncul akibat perbedaan dalam kualitas sumberdaya manusia (Azizah, Sudarti, \& Kusuma, 2018). Kualitas sumberdaya manusia yang rendah berarti produktivitasnya rendah, yang pada gilirannya upahnya rendah. Rendahnya kualitas sumberdaya manusia ini karena rendahnya pendidikan, nasib yang kurang beruntung, adanya diskriminasi, atau karena keturunan dan penyebab kemiskinan ini bermuara pada teori lingkaran setan kemiskinan (vicious circle of poverty) (Mustika, 2013).

Kemiskinan secara umum disebabkan oleh dua faktor yaitu faktor internal dan faktor eksternal. Faktor Internal disebabkan oleh penduduk sendiri contoh rendahnya tingkat pendidikan, rendahnya keterampilan, dan budaya (Kadir, 2014). Sedangkan kemiskinan yang diakibatkan Faktor Eksternal antara lain rendahnya kemampuan mengakses sumberdaya ekonomi, dan diakibatkan oleh bencana termasuk wabah corona bisa menjadikan seseorang menjadi miskin (Nurhidayat, 2020). Pemerintah mengupayakan 
penggelontoran kredit mikro bagi usaha kecil dan mikro yang merupakan bagian dari upaya untuk mengentaskan kemiskinan. Besar sekali harapan akan keberhasilan program ini, mengingat tumbuhnya UMKM karena mampu menyerap tenaga kerja diyakini akan memberikan dampak yang signifikan bagi upaya pengentasan kemiskinan (Nasution \& Ramadhan, 2019).

Upaya lain yang dilakukan dalam mengatasi kemiskinan adalah dengan pengembangan ekonomi kerakyatan yang harus diprioritaskan melalui pemberdayaan sektor Usaha Mikro Kecil dan Menengah (UMKM) (Indika \& Marliza, 2019). UMKM berperan dalam pertumbuhan ekonomi, penyerapan tenaga kerja dan pendistribusian hasilhasil pembangunan. Tujuan pokok dari kebijaksanaan pemberdayaan UMKM adalah untuk meningkatkan produktifitas UMKM, mendorong efektifitas program dan kegiatan yang berkaitan dengan pemberdayaan UMKM (Kurniawan \& Fauziah, 2014). Pemberdayaan dan pengembangan UMKM merupakan salah satu cara untuk menanggulagi kemiskinan yang terjadi. Caranya adalah memberikan akses kepada penduduk miskin untuk dapat terlibat dalam berusaha dan aktif dalam kegiatan usaha yang produkif dan memasyarakatkan kewirausahaan terutama dikalangan keluarga miskin atau daerah tertinggal (Andiny \& Nurjannah, 2018). Pengembangan UMKM melalui peningkatan usaha dan keterampilan pengelolaan usaha, akses lembaga keuangan dan sekaligus meningkatkan kepastian dan perlindungan usaha yang mandiri untuk siap tumbuh dan bersaing dengan pelaku ekonomi lainnya (Krisnawati, 2016). Tujuan Penelitian ini untuk meningkatkan produktivitas UMKM, mendorong efektivitas program dan kegiatan yang berkaitan dengan pemberdayaan UMKM.

\section{METODE PENELITIAN}

Jenis penelitian yang digunakan adalah penelitian kualitatif dengan metode literatur review yaitu penelitian yang menggunakan beberapa kajian untuk kemudian dapat dipahami dan dijadikan dalam satu bentuk pemaparan. Kami mengumpulkan teori-teori dari beberapa sumber yang berasal dari artikel maupun buku-buku yang relevan.

\section{HASIL DAN PEMBAHASAN}

Berdasarkan UU No. 20 tahun 2008 tentang Usaha Mikro, Kecil dan Menengah, bahwa Usaha Mikro adalah usaha produktif milik orang perorangan dan/atau badan usaha perorangan yang memenuhi kriteria Usaha Mikro yaitu modalnya maksimal Rp 50 juta, sedangkan omzetnya mencapai Rp. 300 juta. Usaha Kecil adalah usaha ekonomi produktif yang berdiri sendiri, yang dilakukan oleh orang perorangan atau badan usaha yang bukan merupakan anak perusahaan atau bukan cabang perusahaan yang dimiliki, dikuasai, atau menjadi bagian baik langsung maupun tidak langsung dari usaha menengah atau usaha besar yang memenuhi kriteria modal maksimal sebesar Rp. 500.000.000 dengan omzet maksimal Rp. 2,5 M. Seperti kita ketahui, UMKM adalah sektor yang paling fleksibel dalam menyerap tenaga kerja secara cepat dan alamiah dibandingkan sektor lain. Jumlah yang banyak serta sebaran yang merata, menjadikan sektor ini tidak hanya mampu menciptakan pertumbuhan namun sekaligus mengurangi disparitas antar daerah.

Usaha Mikro Kecil Menengah (UMKM) mempunyai peran penting dalam pembangunan ekonomi. karena tingkat penyerapan tenaga kerjanya yang relatif tinggi dan kebutuhan modal investasinya yang kecil,UMKM bisa dengan fleksibel menyesuaikan dan menjawab kondisi pasar yang terus berubah kemampuan UMKM untuk bersaing di era perdagangan bebas, baik di pasar domestik maupun di pasar ekspor, sangat ditentukan oleh dua kondisi utama yang perlu dipenuhi. Pertama, lingkungan internal UMKM yang 
kondusif, mencakup aspek kualitas SDM, penguasaan teknologi dan informasi, struktur organisasi, sistem manajemen kultur/budaya bisnis, kekuatan modal, jaringan bisnis dengan pihak luar, dan tingkat kewirausahaan (entrepreneurship). Kedua, lingkungan eksternal harus juga kondusif, yang terkait dengan kebijakan pemerintah, aspek hukum,kondisi persaingan pasar, kondisi ekonomi sosial kemasyarakatan, kondisi infrastruktur, tingkat pendidikan masyarakat, dan perubahan ekonomi global.

Karakteristik UKM yang memiliki keunggulan kompetitif meliputi memiliki kualitas SDM yang baik, pemanfaatan teknologi yang optimal, mampu melakukan efisiensi dan meningkatkan produktivitas, mampu meningkatkan kualitas produk, memiliki akses promosi yang luas, memiliki sistem manajemen kualitas yang terstruktur, sumber daya modal yang memadai, memiliki jaringan bisnis yang luas, dan memiliki jiwa kewirausahaan". Mengelola UMKM memerlukan kreativitas yang tinggi, rasa tidak cepat menyerah, berani mengambil risiko, dan selalu berusaha menemukan hal-hal baru untuk meningkatkan kinerja. UMKM memiliki peluang yang sangat besar untuk menjadi besar dan memiliki daya saing, jika saja memiliki manajemen yang solid. Dengan demikian diperlukan sebuah model manajemen UMKM yang dapat dijadikan pedoman oleh UMKM dalam mengelola usahanya. Pelaku UMKM juga harus mampu melakukan analisis SWOT atas usahanya sehingga mampu menilai keadaan sekarang, baik terhadap pesaing, maupun perkembangan usaha dan evaluasi usahanya.

Sebagian besar usaha kecil tumbuh secara tradisional dan merupakan usaha keluarga yang turun temurun. Keterbatasan kualitas SDM usaha kecil baik dari segi pendidikan formal maupun pengetahuan, tekhnik produksi dan keterampilannya sangat berpengaruh terhadap manajemen pengelolaan usahanya, sehingga usaha tersebut sulit untuk berkembang dengan optimal. Dalam pengembangan UMKM, langkah ini tidak sematamata merupakan langkah yang harus diambil oleh Pemerintah dan hanya menjadi tanggung jawab Pemerintah. Pihak UMKM sendiri sebagai pihak internal yang dikembangkan, dapat mengayunkan langkah bersama-sama dengan Pemerintah. Karena potensi yang mereka miliki mampu menciptakan kreativitas usaha dengan memanfaatkan fasilitas yang diberikan oleh pemerintah. Berikut beberapa hal penting yang perlu ditingkatkan bagi pemilik UMKM :

\section{a. Peningkatan Manajemen Keuangan}

Masalah yang dihadapi oleh Usaha Kecil dan Menengah (UKM) dapat dikelompokan menjadi dua yaitu masalah finansial dan masalah non finansial (organisasi manajemen). Masalah yang termasuk dalam masalah finansial diantaranya adalah kurangnya kesesuaian (terjadinya mismatch) antara dana yang tersedia dan dana yang dapat diakses oleh usaha kecil dan menengah, tidak adanya pendekatan yang sistematis dalam pendanaan usaha kecil dan menengah, biaya transaksi yang tinggi, yang disebabkan oleh prosedur kredit yang cukup rumit sehingga menyita banyak waktu sementara jumlah kredit yang dikucurkan sangat kecil, kurangnya akses ke sumber dana yang formal, bunga kredit untuk investasi maupun modal kerja yang tinggi, banyaknya Usaha Kecil dan Menengah (UKM) yang belum bankable, baik disebabkan karena belum adanya manajemen keuangan yang transparan maupun kurangnya kemampuan manajerial dan finansial (Maretha, Sepriansyah, \& Gunawan, 2018).

Manajemen keuangan diartikan sebagai seluruh aktivitas atau kegiatan bisnis yang berhubungan dengan upaya untuk mendapatkan dana usaha dengan cara meminimalkan biaya serta upaya penggunaan dan pengalokasian dana secara efisien dalam memaksimalkan nilai bisnis. Setiap bisnis membutuhkan struktur keuangan yang menghasilkan laba agar tetap bisa persisten dan kredibel. Sehingga yang dibutuhkan pengusaha adalah kemampuan Manajemen Keuangan yang baik, untuk membawa bisnis mereka menuju kesuksesan. Berikut tips untuk memaksimalkan cara membangun 
Manajemen Keuangan yang baik bagi UMKM Hindari Kredit Mahal, fokus pada hal-hal yang berbau 'biaya' pertahankan batas antara keuangan pribadi dengan keuangan usaha. Evaluasi pergerakan keuangan usaha secara konsisten.

\section{b. Memasarkan dan Menjual Produk}

Salah satu masalah besar yang dihadapi dalam pemberdayaan UMKM adalah rendahnya akses UMKM terhadap pasar. Secara konseptual diketahui bahwa empat unsur yang memengaruhi keberhasilan suatu perusahaan dalam berkompetisi adalah produk, harga, tempat/lokasi dan promosi. Keempat faktor strategis ini saling terkait dalam meningkatkan fungsi pemasaran. Dalam era keterbukaan ini dimana batas-batas ruang sudah mulai ditinggalkan peran faktor promosi yang terkait dengan ruang yang sangat luas mulai memperlihatkan pengaruh dominannya.

Secara internal beberapa kendala yang sering muncul pada UMKM dalam hal peningkatan pemasaran produk antara lain : Kurangnya pengetahuan mengenai teknologi produksi terbaru dan cara menjalankan quality control terhadap produk, Kemampuan membaca kebutuhan pasar masih belum tajam, sehingga belum mampu menangkap dengan cermat kebutuhan yang diinginkan pasar, Pemasaran produk masih mengandalkan cara sederhana mouth to mouth marketing (pemasaran dari mulut ke mulut). Belum menjadikan media sosial atau jaringan internet sebagai alat pemasaran.

Kinerja UMKM dapat ditingkatkan dan dikembangkan, maka UMKM harus melakukan beberapa hal, yaitu mengembangkan sasaran pemasarannya, mengembangkan wilayah pemasarannya, menetapkan harga jual sesuai kemasan, mengembangkan saluran pemasarannya, mempertahankan ciri khas produk, mengembangkan berbagai pilihan produk \& kemasan, memperhatikan keinginan dan kebutuhan konsumen, serta melakukan inovasi hasil produksi, untuk menarik daya minat masyarakat agar masyarakat tidak bosan dan dapat memilih sesuai selera.

Sumber daya manusia adalah aspek terpenting dalam melakukan usaha. disebagian usaha mikro kecil pemilik usaha masih sering terlibat dalam persoalan teknis, sehingga kurang memikirkan tujuan atau rencana strategis jangka panjang usahanya. Selain itu dari hasil penelitian, mayoritas ilmu pengetahuan serta keterampilan diturunkan dari generasi sebelumnya. Oleh karena itu dari segi kreativitas mereka kurang bisa mengembangkan kemampuan yang dimilikinya. Mengelola SDM bagi usaha mikro dan kecil merupakan sebuah keterampilan yang penting dimiliki pengusaha. Pengelolaan SDM yang dimaksud meliputi kegiatan rekrutmen, seleksi, penempatan, pengembangan, kompensasi (upah), mempertahankan (retention), evaluasi, promosi hingga pengakhiran hubungan kerja. Pemimpin juga harus menyadari potensi masing-masing individu dan memperlakukan karyawan sesuai dengan kemampuan dan bakat masing-masing. Pengembangan potensi dan pelatihan sesuai dengan kapabilitas masing-masing individu dapat membuat karyawan merasa dihargai.

Pengembangan SDM dapat juga dilakukan oleh lembaga non pemerintah dengan memberikan berbagai kegiatan yang dapat meningkatkan pengetahuan kepada pengusaha tentang cara untuk mengembangkan usaha mikro dan kecil yang dijalankannya, memotivasi dan menambah kemampuan agar mampu mengembangkan usaha dengan memberikan solusi terhadap masalah yang dihadapi. Usaha ini diharapkan akan dapat memberikan peningkatan terhadap pendapatan usaha mikro dan sekaligus pada perekonomian umat. 


\section{KESIMPULAN}

Perkembangan usaha mikro kecil di Indonesia yang semakin meningkat setiap tahunnya memberikan agin segar bagi bangkitnya sektor perekonomian, selain peran UMKM yang dapat mengurangi kemiskinan dan pengangguran juga dapat meratakan perekonomian serta memberikan devisa bagi negara. Dibalik ketangguhan puluhan juta UMKM, upaya pengembangan UMKM masih menjumpai berbagai kendala seperti pengelolaan usaha yang masih tradisional, kualitas Sumber Daya Manusia (SDM) yang belum memadai, skala dan teknik produksi yang rendah serta masih terbatasnya akses kepada lembaga keuangan, khususnya perbankan. Mengelola UMKM memerlukan kreativitas dan inovasi yang perlu terus ditingkatkan agar kinerja pun ikut meningkat. UMKM memiliki peluang yang sangat besar untuk menjadi besar dan memiliki daya saing, jika saja memiliki manajemen yang solid dan mampu melakukan analisis SWOT atas usahanya sehingga dapat menilai keadaan sekarang, baik terhadap pesaing, maupun perkembangan usaha dan evaluasi usahanya.

\section{BIBLIOGRAFI}

Abdillah Ahsan, S. E., Wiyono, M. N. H., Ir, M., \& Demografi, L. (2018). Riset Standard Kebutuhan Hidup Layak (Had Kifayah) di Indonesia.

Andiny, Puti, \& Nurjannah, Nurjannah. (2018). Analisis Pemberdayaan Usaha Mikro Kecil dan Menengah (UMKM) sebagai upaya Penanggulangan Kemiskinan di Kota Langsa. Jurnal Serambi Ekonomi Dan Bisnis, 5(1), 31-37.

Azizah, Elda Wahyu, Sudarti, Sudarti, \& Kusuma, Hendra. (2018). Pengaruh pendidikan, pendapatan perkapita dan jumlah penduduk terhadap kemiskinan di Provinsi Jawa Timur. Jurnal Ilmu Ekonomi JIE, 2(1), 167-180.

Darmawan, Awang, \& Desiana, Rina. (2021). Zakat dan Pemerataan Ekonomi di Masa Pandemi Covid-19. Al-Azhar Journal of Islamic Economics, 3(1), 12-21.

Fadhli, Khotim, Himmah, Shoviatur Rohmatul, \& Taqiyuddin, Akhmad. (2021). Analisis Perubahan Pola Konsumsi Masyarakat Penerima Bantuan Sosial Pada Masa Pandemi Covid-19. Jurnal Education And Development, 9(3), 110-117.

Indika, Miki, \& Marliza, Yayuk. (2019). Upaya Pemberdayaan Usaha Mikro Kecil Menengah (UMKM) Dalam Mengatasi Kemiskinan di Kecamatan Tugumulyo Kabupaten Musi Rawas. Journal Management, Business, and Accounting, 18(3), 4966.

Kadir, Nurhira A. (2014). Menelusuri akar masalah rendahnya presentase pemberian Asi eksklusif di Indonesia. Jurnal Al Hikmah, 15(1), 106.

Kadji, Yulianto. (2012). Kemiskinan dan Konsep teoritisnya. Guru Besar Kebijakan Publik Fakultas Ekonmi Dan Bisnis UNG.

Krisnawati, Krisnawati. (2016). Upaya Penanggulangan Kemiskinan Melalui Pemberdayaan Usaha Mikro Kecil Dan Menengah. Sosio Informa, 2(2).

Kurniawan, Ferry Duwi, \& Fauziah, Luluk. (2014). Pemberdayaan Usaha Mikro Kecil dan Menengah (UMKM) dalam Penanggulangan Kemiskinan. JKMP (Jurnal Kebijakan Dan Manajemen Publik), 2(2), 165-176.

Maipita, Indra. (2013). Memahami dan Mengukur Kemiskinan. Absolute Media.

Maretha, Fetty, Sepriansyah, Sepriansyah, \& Gunawan, Ahmad Ari. (2018). Model Penerapan Informasi Pada Usaha Kecil Dan Menengah Di Kota Palembang. Eksis: Jurnal Riset Ekonomi Dan Bisnis, 13(2), 93-100.

Mustika, Made Dwi Setyadhi. (2013). Analisis Strategi Peningkatan Kualitas Sumber Daya Manusia Dalam Upaya Pengentasan Kemiskinan Di Kecamatan Nusa Penida. Buletin 
Volume 2, Nomor 2, Februari 2022

p-ISSN 2774-7018; e-ISSN 2774-700X

Studi Ekonomi, 44231.

Nasution, Dito Aditia Darma, \& Ramadhan, Puja Rizqy. (2019). MONOGRAF: Persepsi Usaha Mikro Kecil dan Menengah tentang Akuntansi di Kecamatan Datuk Bandar Kota Tanjung Balai. Uwais Inspirasi Indonesia.

Nurhidayat, Nurhidayat. (2020). Pendekatan Ekonomi Syariah Dalam Menyelesaikan Masalah Ekonomi Akibat Pandemi Covid-19. Islamic Banking: Jurnal Pemikiran Dan Pengembangan Perbankan Syariah, 6(1), 17-34.

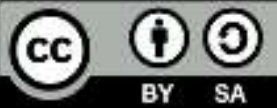

This work is licensed under a Creative Commons Attribution-ShareAlike 4.0 International License. 